\title{
Influence of In vitro Digestion on Antioxidative Activity of Coconut Meat Protein Hydrolysates
}

\author{
Bei Jin ${ }^{1,2 *}$, Xiaosong Zhou ${ }^{1}$, Bing $\mathrm{Li}^{2}$, Weiting Lai ${ }^{1}$ and Xiyin $\mathrm{Li}^{1}$ \\ ${ }^{1}$ School of Chemistry and Chemical Engineering, Lingnan Normal University, Zhanjiang 524048, ${ }^{2}$ Engineering Research Center \\ of Starch and Vegetable Protein Processing, Ministry of Education, South China University of Technology, Guangzhou 510640, \\ China
}

*For correspondence: Email: jinbeikim2013@163.com; Tel/Fax: +86-759-3174025

\begin{abstract}
Purpose: To investigate the antioxidative stability of coconut meat protein hydrolysates (CMPHs) in the gastrointestinal tract, and evaluate the changes in antioxidant activity, amino acid composition and molecular weight distribution of CMPHs during gastrointestinal (GI ) digestion

Methods: A two-stage in vitro digestion model (pepsin treatment for $2 \mathrm{~h}$ followed by pancreatin treatment for $2 \mathrm{~h}$, both at $37^{\circ} \mathrm{C}$ ) was used to simulate the process of $\mathrm{Gl}$ digestion to determine changes in antioxidant activities, namely, 1,1- diphenyl-2-picrylhydrazyl and hydroxyl radical scavenging and reducing power, of CMPHs previously prepared by papain digestion.

Results: Based on the in vitro pepsin-pancreatin simulated GI digestion, it was found that there were more free amino acids and smaller oligopeptides with $M W<500 \mathrm{Da}$ in the final Gl digests. Compared with blank, enzymatic breakdown of the Gl digests increased their hydroxyl (by $11.8 \%$ ) and reducing power (by $71.8 \%$ ).

Conclusion: $\mathrm{CMPHs}$ are high value-added antioxidants and possess a potential capacity to resist gastrointestinal digestion, which makes them promising ingredients for formulation of functional foods.
\end{abstract}

Keywords: Coconut meat protein, Hydrolysates, Simulated gastrointestinal digestion, Antioxidative stability, Oligopeptides, Functional foods

Tropical Journal of Pharmaceutical Research is indexed by Science Citation Index (SciSearch), Scopus, International Pharmaceutical Abstract, Chemical Abstracts, Embase, Index Copernicus, EBSCO, African Index Medicus, JournalSeek, Journal Citation Reports/Science Edition, Directory of Open Access Journals (DOAJ), African Journal Online, Bioline International, Open-J-Gate and Pharmacy Abstracts

\section{INTRODUCTION}

Considerable evidences had confirmed that free radicals were involved in the oxidation of lipids, and oxidative decomposition of unsaturated fatty acids was the primary cause of the development of undesirable off-flavours, odours and potentially toxic reaction products [1,2]. Moreover, free radicals are believed to play a significant role in the occurrence of many chronic diseases, such as diabetes, cardiovascular diseases, neurodegenerative disorders and cancer [3,4]. Therefore, there is a growing interest tin finding antioxidants from natural sources including some dietary protein compounds which may have less health hazard than synthetic antioxidants.

Protein hydrolysates have been found to possess strong in vitro antioxidant activities, such as soy, Sphyrna lewini muscle, loach (Misgurnus anguillicaudatus) and pea [5-8]. The gastrointestinal $(\mathrm{Gl})$ tract is known to be a major oxidation site in the human body [9]. The net effectiveness of foodborne antioxidants depends on their actual level in the $\mathrm{Gl}$ tract. Thus, there is a need to investigate the stability of antioxidants in the $\mathrm{GI}$ tract. 
Coconut (Cocos nucifera L.) is a monocotyledonous plant of the Arecaceae family widely distributed in the tropical areas of Asia, Africa, Latin America, and the Pacific region. Coconuts are an important commodity in Guangdong, China. Coconut fruit is composed of about $38.5 \%$ shell, $51.7 \%$ kernel and $9.8 \%$ water [10]. Fresh coconut meat ("kernel") is 35.2 $\%$ fat, $3.8 \%$ protein and $40 \%$ moisture [11]. Coconut oil and protein can be extracted from dried and fresh coconut meat. Even though the protein content of coconuts meat is low (4\%), the large amount of coconut grown could make the recovery of the protein economically attractive. An estimated 1.6 million tons of protein from fresh coconut or 0.4 million tons from copra on a world-wide basis is potentially available for human consumption. As well as being highly nutritious, coconut meat protein also has excellent functional properties with foaming and emulsifying capacities greater than many legume and oilseed proteins, which is already used extensively as a food ingredient [12].

Moreover, previous studies have shown that coconut meat protein had beneficial anti peroxidative and cardioprotective effect on alcohol and isoproterenol treated rats as well as on human volunteers $[13,14]$. However, the protein fraction is either discarded or used as animal feed presently. It is of great significance, therefore, to find an effective way to utilise this protein source.

The results from our previous studies have established that coconut meat hydrolysates and peptides are potential antioxidants for food applications [15]. However, the degradation and the performance of coconut meat protein hydrolysates during gastrointestinal digestion are unclear. In this work, the influence of in vitro GI digestion on the stability and effectiveness of protein hydrolysates from coconut meat was investigated.

\section{EXPERIMENTAL}

\section{Materials and chemicals}

Fresh matured coconuts (hybrid Mawa variety) used in these experiments were purchased from a local market in Zhanjiang, China. The matured coconuts consisted of hard outer shell which enclosed the test. After cracking the nuts and discarding the coconut water, the meat was removed from the shells and manually pared, and only the pared meat was used for all experiments. The fat content of coconut meat
(53.10\%), protein content (6.38\%), and average moisture (46.36 \%) on wet basis were determined by the standard Association of Official Analytical Chemists method (AOAC, 1984). Coconut meat was separated, pulverized and defatted using petroleum ether $\left(60-80{ }^{\circ} \mathrm{C}\right)$ for 2 - $3 \mathrm{~h}$. The defatted meal was grounded to pass through a $15 \mathrm{~mm}$ screen sieve. The ground meal was freeze-dried and stored at $-20{ }^{\circ} \mathrm{C}$ until needed. Alcalase 2.4 L (EC 3.4.21.62, from Bacillus licheniformis, $2.4 \mathrm{AU} / \mathrm{g}$ ) was obtained from Baiao Biochemistry Co. (Jiangmen, China). Pepsin (2500-3500 units/mg protein), pancreatin (8 $x$ the standard USP unit), 1,1-diphenyl-2picrylhydrazyl (DPPH) were obtained from Sigma-Aldrich (St. Louis, MO, USA). All other chemicals and reagents used were of analytical grade and obtained from Zixing Reagent Co. (Guangzhou, China).

\section{Preparation of coconut meat protein}

Defatted material was stirred with $\mathrm{pH} 8.0$ phosphate buffer in large containers using mechanical stirrer for $24 \mathrm{~h}$ at $4{ }^{\circ} \mathrm{C}$. The saline extract was collected and by adjusting the $\mathrm{pH} 4.0$ with dilute $\mathrm{HCl}$ solution, the proteins were precipitated. The solution was centrifuged at $5000 \mathrm{r} / \mathrm{min}$ for $10 \mathrm{~min}$ and the precipitated globulin fraction was collected, washed with distilled water 3 times, freeze-dried and stored at $-20{ }^{\circ} \mathrm{C}$ until needed.

\section{Preparation of coconut meat hydrolysates (CMPHs)}

Ten grams of coconut meat protein were mixed with $100 \mathrm{~mL}$ of distilled water and homogenised at a speed of $8000 \mathrm{rpm}$ for $5 \mathrm{~min}$ using a basic homogeniser (T25, Ika, Staufen, Germany). The homogenate was hydrolysed with Alcalase at 50 ${ }^{\circ} \mathrm{C}$ for $7 \mathrm{~h}$ to obtain a hydrolysate that was previously shown to have strong antioxidative activity. The enzyme concentration is $14000 \mathrm{U} / \mathrm{g}$. The hydrolysis was conducted at $\mathrm{pH} 10.5$ (SL1PHS-3B pH-meter, Wuhan Midwest Instrument Co. Ltd., Wuhan, China) in a water bath shaker (New Brunswick Scientifics C24, Jintan, China). After hydrolysis, the enzyme was inactivated by placing the glass-stoppered bottle which contained the enzyme and the substrate in boiling water for $15 \mathrm{~min}$. The hydrolysates were centrifuged using a GL-21 $M$ refrigerated centrifuge (Xiangyi Instrument Co. Ltd, Changsha, China) at $5000 \mathrm{~g}$ for $20 \mathrm{~min}$ and the supernatants were then lyophilized (R2L100KPS, Kyowa Vacuum Engineering, Tokyo, Japan) and stored in a desiccator for further use. 


\section{Hydroxyl radical scavenging activity assay}

Hydroxyl radical scavenging activity was assayed using a modification of the method described by $\mathrm{Li}$ et al [16]. A mix of $600 \mu \mathrm{L}$ of 1,10phenanthroline $(5.0 \mathrm{mM}), 600 \mu \mathrm{L}$ of $\mathrm{FeSO}_{4}(5.0$ $\mathrm{mM})$ and $600 \mu \mathrm{L}$ of ethylenediaminetetraacetic acid (EDTA) $(15 \mathrm{mM})$ were mixed with $400 \mu \mathrm{L}$ of sodium phosphate buffer $(0.2 \mathrm{M}, \mathrm{pH} 7.4)$. Then $600 \mu \mathrm{L}$ of $\mathrm{Gl}$ digests $(2.0 \mathrm{mg} / \mathrm{mL})$ and $800 \mu \mathrm{L}$ of $\mathrm{H}_{2} \mathrm{O}_{2}(0.01 \%)$ were added. The mixture was incubated at $37{ }^{\circ} \mathrm{C}$ for $60 \mathrm{~min}$, and the absorbance was measured at $536 \mathrm{~nm}$ (UV754, Xianjian Scientific Instrument Co., Shanghai, China). Hydroxyl radical scavenging activity $(\mathrm{H})$ was determined as in Eq 1.

$H(\%)=\left(A_{s}-A_{0}\right) \times 100 /\left(A_{c}-A_{0}\right)$

where $A_{s}$ is the absorbance of the sample; $A_{0}$ is the absorbance of the blank solution using distilled water instead of sample; $A_{c}$ is the absorbance of a control solution in the absence of $\mathrm{H}_{2} \mathrm{O}_{2}$.

\section{DPPH radical scavenging activity assay}

DPPH radical-scavenging activity was determined by the method of You et al [7]. The dried GI digests were dissolved in distilled water at $2.0 \mathrm{mg} / \mathrm{mL}$. Thereafter, $2.0 \mathrm{~mL}$ of sample was mixed with $2.0 \mathrm{~mL}$ of $0.15 \mathrm{mM}$ DPPH dissolved in $95 \%$ ethanol. The mixture was then shaken vigorously a mixer (QT-1 Mixer, Tianchen Technological Co. Ltd, Shanghai, China) and kept for $30 \mathrm{~min}$ in the dark. The absorbance of the resulting solution was recorded spectrophotometricallyat $517 \mathrm{~nm}$ and scavenging activity (S) was calculated as in Eq 2.

$S(\%)=\{(A s-A c) / A b\} 100$

where As is the absorbance of DPPH sample (i.e., $2 \mathrm{~mL}$ of sample solution mixed with DPPH solution); Ac is the absorbance of control (i.e., 2 $\mathrm{mL}$ of sample solution mixed with $2 \mathrm{~mL}$ of $95 \%$ ethanol); and $A b$ is the absorbance of blank for DPPH (i.e., $2 \mathrm{~mL}$ of $95 \%$ ethanol mixed with DPPH solution).

\section{Reducing power assay}

The reducing power was determined as previously described [17] with a slight modification. Briefly, $2.0 \mathrm{ml}$ of sample was mixed with $2.0 \mathrm{ml}$ of $0.2 \mathrm{M}$ sodium phosphate buffer $(\mathrm{pH}$ $=6.6)$ and $2.0 \mathrm{ml}$ of $1 \%(\mathrm{w} / \mathrm{v})$ potassium ferricyanide. The mixture was then incubated at $50{ }^{\circ} \mathrm{C}$ for $20 \mathrm{~min}$. Then, $2.0 \mathrm{ml}$ of $10 \%$ trichloroacetic acid were added. After centrifugation at $3000 \mathrm{r} / \mathrm{min}$ for $10 \mathrm{~min}, 2.0 \mathrm{ml}$ of the supernatant were collected and mixed with $2.0 \mathrm{ml}$ of distilled water and $0.4 \mathrm{ml}$ of $0.1 \%(\mathrm{w} / \mathrm{v})$ $\mathrm{FeCl} 3$. After standing at room temperature for 10 min, the absorbance was measured spectrophotometrically at $700 \mathrm{~nm}$. Higher absorbance indicated stronger reducing power. An equivalent volume of distilled water instead of the sample was used as the blank.

\section{In vitro pepsin-pancreatin simulated GI digestion}

The $\mathrm{Gl}$ digestion (an in vitro pepsin-pancreatin hydrolysis) was simulated according to the published methods with slight modifications [18]. CMPHs were re-dissolved ( $3.5 \% \mathrm{w} / \mathrm{v})$ in a buffer solution of $0.1 \mathrm{M} \mathrm{KCl}-\mathrm{HCl}$, and adjusted the $\mathrm{pH}$ to 2.0 with $1 \mathrm{M} \mathrm{HCl}$. Then pepsin (4\% enzyme/substrate, $w / w$ ) was added. The mixture was incubated at $37^{\circ} \mathrm{C}$ for $2 \mathrm{~h}$, after which it was adjusted to $\mathrm{pH} 5.3$ with a solution of $0.9 \mathrm{M}$ $\mathrm{NaHCO}_{3}$ solution and further to $\mathrm{pH} 7.5$ with 1.0 $\mathrm{M} \mathrm{NaOH}$. Pancreatin (4\% enzyme/substrate, $\mathrm{w} / \mathrm{w})$ was added, and the mixture was further incubated at $37{ }^{\circ} \mathrm{C}$ for $2 \mathrm{~h}$. In due time, the test tubes were kept in boiling water for $10 \mathrm{~min}$ to terminate the reaction. The $\mathrm{Gl}$ digests were cooled down to room temperature and centrifuged at $11000 \mathrm{~g}$ for $15 \mathrm{~min}$. The supernatant was lyophilized, and stored at -20 ${ }^{\circ} \mathrm{C}$ for further analysis. The test was carried out in triplicate. To investigate the changes in antioxidative activity of CMPHs digests during the simulated $\mathrm{Gl}$ digestion, aliquots of $\mathrm{Gl}$ digests were removed at 0 (Alcalase hydrolysate), 0.5, 1.0, 1.5, 2.0, (switch from pepsin to pancreatin) $2.5,3.0,3.5$ and 4.0 during the digestion in vitro.

\section{Amino acid analysis}

The digest samples were precipitated with $10 \%$ cold trichloroacetic acid for $2 \mathrm{~h}$ and then centrifuged at $11000 \mathrm{~g}$ for $15 \mathrm{~min}$. The $\mathrm{pH}$ of the supernatant was adjusted to 2.0 , and the solution was passed through a membrane $(0.22 \mu \mathrm{m})$. Then the filtrate was subjected to RP-HPLC analysis (Agilent HP1100) after precolumn derivatizing with PITC as indicated above to determine the free amino acid compositions according to the method of Zhu et al [18].

\section{Determination of molecular weight distribution}

The MW distribution of the digests was determined by gel permeation chromatography on a Superdex Peptide HR 10/300 GL column $(10 \times 300 \mathrm{~mm}$, Amersham Biosciences Co., Piscataway, NJ, USA) with a UV detector at 214 
and $280 \mathrm{~nm}$. The mobile phase (isocratic elution) was $0.02 \mathrm{M}$ sodium phosphate buffer containing $0.25 \mathrm{M} \mathrm{NaCl}(\mathrm{pH} 7.2)$, at a flow rate of 0.5 $\mathrm{mL} / \mathrm{min}$. Six standard molecular markers, cytochrome C (12,500 Da), aprotinin (6500 Da), vitamin B12 (1355 Da), oxidized glutathione (612 $\mathrm{Da}$ ) and glycylglycylglycine (189 Da) (Sigma Co., St. Louis, MO, USA), were used to calculate MW of the digests. UNICORN 5.0 software (Amersham Biosciences Co., Piscataway, NJ, USA) was used to analyze the chromatographic data.

\section{Statistical analysis}

All the experiments were carried out in triplicate and values expressed as mean \pm (standard deviation (SD). The results were subjected to one-way analysis of variance (ANOVA). Duncan's new multiple range test was performed to determine significant difference between samples at $95 \%$ confidence interval, using SPSS 13.0 software (SPSS Inc, Chicago, IL, USA).

\section{RESULTS}

The DPPH, hydroxyl radical scavenging abilities and reducing power were used as the standards to assess the antioxidative activity of CMPHs after in vitro gastrointestinal digestion and the results are shown in Fig 1.

\section{DPPH radical-scavenging activity}

After pepsin digestion, the DPPH radicalscavenging activity of $\mathrm{CMPHs}$ increased from $83.07 \pm 1.57$ to $88.45 \pm 1.07 \%$ (shown in Fig 1a). This same trend was also reported by You et al. Specifically, more hydrophobic amino residue side chain groups were expected to be exposed, which would make the peptides more accessible to the DPPH radicals and allow them to trap the radicals more easily during the pepsin digestion [7]. A sharp decrease $(p<0.05)$ of DPPH radical scavenging activity from $88.45 \pm 1.07$ to $40.69 \pm$ $0.76 \%$ was observed after $0.5 \mathrm{~h}$ pancreatin digestion $(2.5 \mathrm{~h})$. Pancreatin digestion for $4 \mathrm{~h}$ brought a markedly decrease in inhibition (more than $50 \%$ of the antioxidative activity lost), which was in accord with the previous study made by Zhu et al, who confirmed that the increasing polarity of the pancreatin digest makes it more difficult to react with the lipid-soluble DPPH radicals [18].

\section{Hydroxyl radical scavenging activity}

Hydroxyl radical scavenging activity of CMPHs during the simulated $\mathrm{Gl}$ digestion were shown in Fig 1a, which decreased significantly upon pepsin digestion $(p<0.05)$. Especially, after 0.5 $\mathrm{h}$ of digestion by pepsin, the hydroxyl radical activity of the GI digest was dramatically reduced by $23.2 \%(p<0.05)$ while further incubation with pepsin did not bring any further significant changes of activity. However, further digestion by pancreatin brought the hydroxyl radical scavenging activity of the final Gl digest to 90.42 $\pm 1.28 \%$ (i.e., $11.8 \%$ increase compared to blank) $(p<0.05)$. The changing tendency of the hydroxyl radical scavenging activity of GI digests was different from that of the DPPH radical scavenging activity. That is because, after in vitro
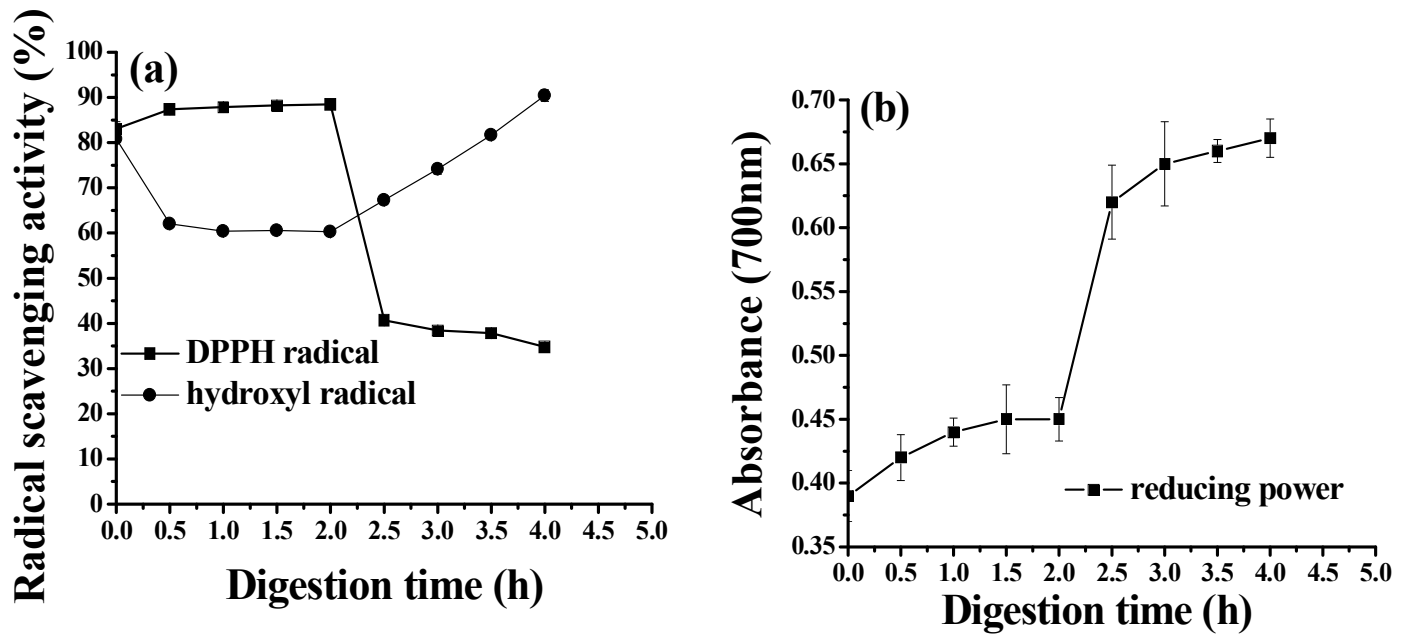

Fig 1: Changes in hydroxyl (a), DPPH (a) radical scavenging activity and reducing power (b) of CMPHs during sequential in vitro digestion. The data with different lowercase letters in the same test are significantly $(p<0.05)$ different 
digesting, coconut meat peptides can be more effective hydrogen or electron donors. As a result, the antioxidative efficacy of CMPHs would approximately be $100 \%$, suggesting that new peptides with antioxidative activities were formed during GI digestion, and might increase the antioxidative efficacy.

\section{Reducing power}

The reducing power assay is used to evaluate the antioxidative activity based on its ability to reduce $\mathrm{Fe}^{3+}$ /ferricyanide complex to the ferrous form through the donation of an electron. As shown in Fig. 6b, the reducing power of the blank was $0.39 \pm 0.02 \%$. It increased by $15.38 \%$ compared to blank during the pepsin digestion. However, it increased significantly after $2 \mathrm{~h}$ of pancreatin digestion $(p<0.05)$. The final $\mathrm{Gl}$ digest showed $71.8 \%$ increase in reducing power compared to the $\mathrm{Gl}$ digest at $0 \mathrm{~h}$, which was in accordance with the report of Zhu et al, who also found an increased reducing power of zein hydrolyates [18].

Amino acid composition and molecular weight distribution of peptides in digests

As shown in Table 1, two-step digestion process substantially increased the content of free amino acids (FAAs) of CMPH. Two-hour pepsin digestion raised the $\mathrm{FAA}$ content of $\mathrm{CMPH}$ by $30.3 \%$ compared to the blank. After further $2 \mathrm{~h}$ digestion with pancreatin, FAA of $\mathrm{CMPH}$ increased drastically by $86.7 \%$ compared to the blank.

The molecular weight profiles show some differences between the gastrointestinal digested CMPHs and control (undigested) (shown in Table 2). During the first $2 \mathrm{~h}$ pepsin hydrolysis, the proportion of $>3000$ Da fraction was reduced by $39.2 \%$; in particular,the $>5000$ Da fraction was degraded significantly $(p<0.05)$. In addition, the $1000 \mathrm{Da}$ to $3000 \mathrm{Da}$ fraction range was reduced by $25.8 \%$ was $(p<0.05)$. By contrast, the oligopeptides < 250 Da increased by $91.2 \%$ ( $p<$ $0.05)$. However, the relative content of 250-1000 Da peptides just increased by $15.2 \%(p<0.05)$. During the following simulated intestinal digestion by pancreatin, the proportion of $>3000 \mathrm{Da}$ fraction were further digested $(p<0.05)$, the proportion of 1000 to 3000 Da fraction was 55.8 $\%$ less $(p<0.05)$. The fraction of $250-1000 \mathrm{Da}$ peptides were slightly increased ( $p>0.05)$, wherein the oligopeptides < $250 \mathrm{Da}$ increased by $97.8 \%(p<0.05)$, compared to those of the $2 \mathrm{~h}$ digest using pepsin. These changes are in accordance with that of the free amino acids described above. Moreover, the final GI digests were rich in < 500 Da fractions (about $65.2 \%$ ).

Table 1: Changes in free amino acid content of CMPHs during sequential in vitro digestion

\begin{tabular}{lccc}
\hline Amino acid & $\begin{array}{c}\text { Undigested } \\
\text { (mg/g protein) }\end{array}$ & $\begin{array}{c}\text { After gastric digestion } \\
\text { (mg amino acid/g Gl } \\
\text { digest powder) }\end{array}$ & $\begin{array}{c}\text { After intestinal } \\
\text { digestion } \\
\text { (mg amino acid/g Gl } \\
\text { digest powder) }\end{array}$ \\
\hline Asp & 3.8 & 4.3 & 6.8 \\
Glu & 25.6 & 26.7 & 28.2 \\
Ser & 5.8 & 7.6 & 11.5 \\
Gly & 4.2 & 4.9 & 7.1 \\
His & 4.5 & 7.9 & 17.5 \\
Thr & 3.6 & 4.2 & 6.4 \\
Ala & 8.4 & 9.1 & 10.3 \\
Pro & 5.6 & 5.9 & 7.5 \\
Arg & 24.2 & 25.4 & 36.4 \\
Tyr & 3.4 & 5.3 & 9.6 \\
Val & 12.1 & 13.7 & 19 \\
Met & 7.7 & 10.3 & 20.4 \\
Cys & 1.9 & 1.9 & 2.1 \\
Ile & 6.7 & 8.2 & 13.4 \\
Leu & 16.5 & 28.4 & 37.3 \\
Phe & 19.9 & 37.5 & 40.1 \\
Lys & 17.4 & 21.7 & 42.5 \\
Trp & 1.4 & 2 & 6.4 \\
Total & 172.7 & 225 & 322.5 \\
\hline
\end{tabular}


Table 2: Protein factions and their molecular weight of Gl digests

\begin{tabular}{lccc}
\hline Molecular weight (Da) & Undigested $^{*}(\%)$ & $\begin{array}{c}\text { After gastric } \\
\text { digestion }\end{array}$ & $\begin{array}{c}\text { After intestinal } \\
\text { digestion* }\end{array}$ \\
\hline$>5000$ & $6.17 \pm 1.22^{\mathrm{a}}$ & $2.34 \pm 0.43^{\mathrm{b}}$ & $0.58 \pm 0.14^{\mathrm{c}}$ \\
$3000-5000$ & $13.1 \pm 1.61^{\mathrm{a}}$ & $9.37 \pm 0.97^{\mathrm{b}}$ & $3.6 \pm 0.47^{\mathrm{ab}}$ \\
$1000-3000$ & $30.33 \pm 1.16^{\mathrm{a}}$ & $22.51 \pm 1.18^{\mathrm{a}}$ & $9.94 \pm 0.84^{\mathrm{b}}$ \\
$500-1000$ & $17.74 \pm 1.51^{\mathrm{a}}$ & $20.41 \pm 2.68^{\mathrm{a}}$ & $20.67 \pm 1.41^{\mathrm{a}}$ \\
$250-500$ & $22.51 \pm 1.93^{\mathrm{c}}$ & $25.96 \pm 1.77^{\mathrm{a}}$ & $26.81 \pm 1.59^{\mathrm{a}}$ \\
$<250$ & $10.15 \pm 1.2^{\mathrm{a}}$ & $19.41 \pm 2.21^{\mathrm{a}}$ & $38.35 \pm 2.17^{\mathrm{a}}$ \\
\hline
\end{tabular}

*Undigested, after gastric digestion, after intestinal digestion, respectively, represent before digestion (0 h), after $2 \mathrm{~h}$ digestion by pepsin, and after following $4 \mathrm{~h}$ digestion by pancreatin; ${ }^{a, b, c}$ data for each molecular weight range of CMPHs at three digestion time points were subjected to statistical analysis. Values with the same lowercase letters are not significantly different $(p>0.05)$

\section{DISCUSSION}

Based on the above results obtained, it can be concluded that the overall antioxidant activities of $\mathrm{CMPHs}$ remained consistently high throughout in vitro digestion. The antioxidative activity of peptides is related to the composition and structural arrangement of amino acids, and influences their bioactivity and digestion stability. The amino acids analysis further supports the idea that the CMPHs were mainly broken into small fragments during pepsin digestion. However, during pancreatin digestion, these peptides were more completely hydrolyzed. Tyr, Met, His, Lys and Arg have generally been considered as antioxidative amino acids [19,20]. As shown in Table 1, the content of the above five free amino acids in $\mathrm{Gl}$ digests increased from 53.8 to $126.4 \mathrm{mg} / \mathrm{g}$. These antioxidative amino acids could act as proton/ electron donors to quench the free radical and promote the antioxidative activity of bioactive peptides, resulting in enhanced radical-scavenging activity and reducing power during digestion. The same findings were noted for peptides isolated from soybean hydrolysate [21] and casein-derived antioxidant peptides [22]. During in vitro digestion, CMPHs are cleaved to small peptides and free amino acids by pepsin and pancreatin. The molecular weight distribution of $\mathrm{Gl}$ digests further confirmed that CMPHs was significantly degraded and produced more small oligopeptides and free amino acids during the simulated GI digestion. The low molecular weight oligopeptides could allow a rapid absorption and a high potential bioactivity [23]. This could be the cause of the enhanced antioxidative activity of $\mathrm{CMPHs}$ after digestion. Therefore, coconut meatderived oligopeptides below $500 \mathrm{Da}$ exhibited the best initial and surviving DPPH, hydroxyl radical scavenging activity and reducing power, which in accordance with the results observed by Ajibola et al [24]. These antioxidant peptides were most likely to be stable in real digestion system after ingestion in both stomach and intestine, which have high proteolytic activity under acidic and alkaline $\mathrm{pH}$, respectively.

\section{CONCLUSION}

The findings of this study show that CMPHs is subject to simulated GI digestion, and more oligopeptides of $<500 \mathrm{Da}$ are formed during intestinal digestion. The FAA of $\mathrm{CMPH}$ is considerably higher than that of blank after digestion. The antioxidative activity of CMPHs is only slightly influenced by pepsin hydrolysis, but further digestion by pancreatin enhances the activity. Thus, coconut meat peptides can be used as food additives and diet nutrients to resist digestive proteases.

\section{ACKNOWLEDGEMENT}

We are grateful for the financial support from Non-Funding Programs for Science and Technology Development of Zhanjiang (no. 2013B01053), supported by Open Project Program of Process of Starch and Vegetable Protein Engineering Research Center of Ministry of Education (no. 2013-ERC-01).

\section{REFERENCES}

1. Bougatef $A$, Nedjar-Arroume $N$, Laïla $M$, Ravallec $R$, Barkia A, Guillochon D, Nasri M. Purification and identification of novel antioxidant peptides from enzymatic hydrolysates of sardinelle (Sardinella aurita) by-products proteins. Food Chem 2010; 118: 559-565.

2. Giménez $B$, Alemán A, Montero $P$, Gómez-Guillén MC. Antioxidant and functional properties of gelatin hydrolysates obtained from skin of sole and squid. Food Chem 2009; 114: 976-983.

3. Moskovitz J, Yim KA, Choke PB. Free radicals and disease. Arch Biochem Biophys 2002; 397: 354-359.

4. Sakanaka S, Tachibana Y. Active oxygen scavenging activity of egg-yolk protein hydrolysates and their 
effects on lipid oxidation in beef and tuna homogenates. Food Chem 2006; 95: 243-249.

5. Moure A, Domínguez H, Parajó JC. Antioxidant properties of ultrafiltration recovered soy protein fractions from industrial effluents and their hydrolysates. Process Biochem 2006; 41: 447-456.

6. Wang B, Li Z R, Chi CF, Zhang QH, Luo HY. Preparation and evaluation of antioxidant peptides from ethanolsoluble proteins hydrolysate of Sphyrna lewini muscle. Peptides 2012; 36: 240-250.

7. You LJ, Zhao MM, Regenstein JM, Ren JY. Changes in the antioxidative activity of loach (Misgurnus anguillicaudatus) protein hydrolysates during a simulated gastrointestinal digestion. Food Chem 2010; 120: 810-816.

8. Pownal TL, Udenigwe CC, Aluko RE. Effects of cationic property on the in vitro antioxidant activities of pea protein hydrolysate fractions. Food Res Int 2011; 44: 1069-1074.

9. rigiridhar K, Nair KM, Subramanian R, Singotamu L. Oral repletion of iron induces free radical mediated alterations in the gastrointestinal tract of rat. Mol Cell Biochem 2001; 219: 91-98.

10. Vigila AG, Baskaran X. Immunomodulatory effect of coconut protein on cyclophosphamide induced immune suppressed Swiss albino mice. Ethno Leaflets 2008; 12: 1206-1212.

11. Kwon KS, Bae D, Park KH, Rhee KC. Aqueous extraction and membrane techniques improve coconut protein concentrate functionality. J Food Sci 1996; 61: 753756.

12. Chakraborty $P$, Mukhopadhyay S, Roy A, Sengupta $T$. Physicochemical characteristics of legumes and oilseed proteins. J Surf Sci Technol 1987; 3: 105-114.

13. Nair KGP, Rajamohan T, Kurup PA. Coconut kernel protein modifies the effect of coconut oil on serum lipids. Plant Food Hum Nutr 1998; 53: 133-144.

14. Mini S, Rajamohan T. Influence of coconut kernel protein on lipid metabolism in alcohol fed rats. Indian J Exp Biol 2004; 42, 53-57.

15. Jin B, Huang MF, He ZP, Shen SQ. Enzymatic hydrolysis of coconut protein and antioxidative activity of the hydrolysates. Modern Food Sci Technol 2013; 29: 1826-1831.

16. Li YH, Jiang B, Zhang T, Mu WM, Liu J. Antioxidant and free radical scavenging activities of chickpea protein hydrolysate (CPH). Food Chem 2008; 106: 444-450.

17. Zheng L, Su GW, Ren JY, Gu LJ, You LJ, Zhao MM. Isolation and characterization of an oxygen radical absorbance activity peptide from defatted peanut meal hydrolysate and its antioxidant properties. J Agric Food Chem 2012; 60: 5431-5437.

18. Zhu LJ, Chen J, Tang XY, Xiong YL. Reducing, radical scavenging, and chelation properties of in vitro digests of alcalase-treated zein hydrolysate. J Agric Food Chem 2008; 56: 2714-2721.

19. Ren JY, Zhao MM, Shi J, Wang JS, Jiang YM, Cui C, Kakuda Y, Xue SJ. Purification and identification of antioxidant peptides from grass carp muscle hydrolysates by consecutive chromatography and electrospray ionization-mass spectrometry. Food Chem 2008; 108: 727-736.

20. You LJ, Zhao MM, Regenstein JM, Ren JY. In vitro antioxidative activity and in vivo anti-fatigue effect of loach (Misgurnus anguillicaudatus) peptides prepared by papain digestion. Food Chem 2011; 124: 188194.

21. Chen H, Muramoto K, Yamauchi F. Structural analysis of antioxidative peptides from soybean.beta.conglycinin. J Agric Food Chem 1995; 43: 574-578.

22. Chen $M, L i B$. The effect of molecular weights on the survivability of casein-derived antioxidant peptides after the simulated gastrointestinal digestion. Innov Food Sci Emerg 2012; 16: 341-348.

23. Rufián-Henares JA, Morales FJ. Effect of in-vitro enzymatic digestion on antioxidant activity of coffee melanoidins and fractions. J Agric Food Chem 2007; 55: 10016-10021.

24. Ajibola CF, Fashakin JB, Fagbemi TN, Aluko RE. Effect of peptide size on antioxidant properties of African yam bean seed (Sphenostylis stenocarpa) protein hydrolysate fractions. Int J Mol Sci 2011; 12: 66856702. 